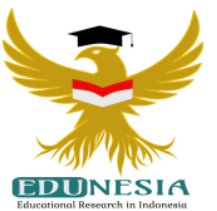

\title{
Analisis Perkembangan Fisik-Motorik Siswa Kelas 3 di Sekolah Dasar Negeri Tajem
}

\author{
Siti Nur Fikriyah \\ Program Studi Magister PGMI, UIN Sunan Kalijaga Yogyakarta, Indonesia \\ Corresponding Email: st.nurfikriyah35@gmail.com, Phone Number : 0812 xxxx xxxx
}

Article History:

Received: Dec 07, 2020

Revised: Dec 08, 2020

Accepted: Dec 10, 2020

Published: Jan 01, 2021

\section{Keywords:}

Basic Age,

Development,

Motoric Physical.

Kata Kunci:

Fisik Motorik,

Perkembangan,

Usia Dasar.

How to cite:

Fikriyah, S.N. (2021)

Analisis Perkembangan

Fisik-Motorik Siswa Kelas 3 di Sekolah Dasar Negeri Tajem. Edunesia: Jurnal Ilmiah Pendidikan, 2 (1): 200207.

This is an open access article under the CC-BY-NC-ND license
Abstract: The purpose of the study was to analyze the physical-motor development of the elementary ade studens achieved. Physical development includes biological growth for example brain growth, muscle and bone. The importance of teachers and parents in honing and monitoring the physicalmotor development of children so that they become independent children in doing anything. Motor development is divided into two, namely gross motoric and fine motoric. Motor development and physical development cannot be separated, because physical development is able to stimulate motor development which is related to movement skills. The study used descriptive qualitative methods obtained by data observation, interview, and documentation. The research was conducted at tajem state primary school. This research sample is one of the 3rd graders at using a study of theories regarding the physical-motor development of the accomplished and unachievable students. The results of the study show that the students 'physical-motoric development as a whole grows well because the teacher carries out various activities in developing the students' physical-motoric development in a better direction in the process.

Abstrak: Penelitian ini bertujuan untuk mengamati suatu perkembangan fisikmotorik anak usia sekolah dasar yang tercapai ketika kegiatan belajar dan mengembangkan perkembangan fisik-motorik anak usia dasar yang selalu guru upayakan. Perkembangan fisik anak berupa pertumbuhan biologis yaitu adanya pertumbuhan otot, pertumbuhan otak, dan pertumbuhan tulang. Pentingnya guru dan orang tua dalam mengasah dan memantau perkembangan fisik-motorik anak agar beranjak dewasa anak mandiri dalam melakukan apapun. Perkembangan motorik terbagi menjadi dua yaitu motorik kasar dan motorik halus. Perkembangan motorik dan perkembangan fisik tidak dapat dipisahkan, sebab perkembangan fisik mampu memberikan merangsang terhadap perkembangan motorik yang memiliki kaitan dengan keterampilan gerak. Penelitian ini menggunakan metode kualitatif deskriptif yang diperoleh data dengan observasi, wawancara, dan dokumentasi. Penelitian ini dilakukan di Sekolah Dasar Negeri Tajem. Sampel penelitian ini adalah seluruh siswa kelas 3 dengan kajian teori perkembangan fisik-motorik siswa berprestasi dan tidak berprestasi. Hasil studi menunjukkan perkembangan fisik-motorik seluruh siswa tumbuh baik sebab guru melakukan berbagai macam kegiatan dalam mengembangkan perkembangan fisik-motorik siswa dalam prosesnya lebih baik lagi. 


\section{A. Pendahuluan}

Perkembangan anak sekolah dasar merupakan kategori yang banyak mengalami perubahan secara drastis baik dari segi mental maupun fisik. Perkembangan anak sekolah dasar berkisar antara $7-12$ tahun. Perkembangan fisik anak usia sekolah dasar mengikuti prinsip yang digunakan umumnya, seperti tipe perubahan, pola pertumbuhan fisik, karakteristik perkembangan, dan perbedaan setiap anak. Tipe perubahan yang cukup spesifik adalah perubahan proporsi yang berupa perubahan tinggi badan dan perubahan berat badan (Puspita dkk, 2018). Pada fase ini, pertumbuhan fisik anak pasti berlangsung dan akan berubah setiap waktu ketika masih dalam masa pertumbuhan. Anak akan bertambah tinggi, berambah kuat, bertambah berat badan, dan lebih banyak belajar berbagai macam keterampilan lainnya dan perkembangan fisik pada masa ini tergolong lambat namun konsisten, sehingga dapat dikenal sebagai masa tenang.

Perkembangan fisik anak sekolah dasar mencakup pertumbuhan biologis misalnya pertumbuhan otak, otot dan tulang. Jika perkembangan fisik anak berkembang dengan baik maka akan berpengaruh terhadap keterampilan motoriknya. Begitupun sebaliknya dengan anak yang perkembangan fisik mengalami gangguan, akan berdampak pada terganggunya kemampuan motorik anak tersebut. Kemampuan motorik dasar itu berperan sebagai landasan bagi keterampilan. Selain itu keterampilan banyak tergantung pada kemampuan dasar (Rinaldi, 2019).

Kemampuan motorik menjadi peranan penting dalam setiap kegiatan. kemampuan motorik yang bagus mampu membuat seseorang melakukan semua kegiatannya dengan baik. Apabila kemampuan motorik tersebut terganggu akan menghambat pada kemampuan lainnya, seperti kemampuan dalam bersosialisasi dan kemampuan dalam melakukan tugas-tugas atau kegiatan sehari-hari. Gangguan fisik-motorik anak yang mengalami kelainan atau cacat sedemikian rupa sehingga memerlukan pelayanan pendidikan khusus (Wicaksono \& Nurhayati, 2013). Untuk mengatasai adanya gangguan perkembangan sejak dini diperlukan pemeriksaan yang diawali sejak dalam kandungan serta asupan gizi yang harus diperhatikan.

Berdasarkan uraian diatas, dalam artikel ini akan membahas lebih mendalam mengenai perkembangan fisik-motorik anak siswa sekolah dasar dengan tujuan untuk mengetahui bagaimana cara guru dalam mempengaruhi perkembangan siswanya dalam kegiatan belajar sehingga siswa mampu dikategorikan dalam perkembangan fisikmotoriknya berkembang dengan baik.

\section{B. Metode}

Penelitian yang digunakan adalah penelitian kualitatif deskriptif. Penelitian kualitatif adalah pendekatan secara primer yang menggunakan paradigma pengetahuan berdasarkan pandangan kontruktivist (Emzir, 2012). Penelitian deskriptif yaitu suatu metode penelitian yang menggambarkan fenomena yang ada dan berlangsung pada masa saat ini atau masa saat lampau. Penelitian ini tidak mengadakan manipulasi namun menggambarkan suatu kondisi sesuai adanya (Munirotul, 2013).

Teknik pengumpulan data yang digunakan yaitu observasi, wawancara, dan dokumentasi. Semua itu dilakukan untuk menjawab semua permasalahan yang memerlukan pemahaman yang mendalam. Data yang diperoleh bersifat deskriptif yang dihimpun dari berbagai sumber. Subjek dalam penelitian ini berupa benda, hal, dan orang 
tempat variabel melekat (Suharsimi, 2010). Subjek penelitiannya yaitu seluruh siswa kelas 3 dan Ibu Fifin selaku wali kelas di kelas 3.

\section{Hasil dan Pembahasan}

Kegiatan fisik merupakan sebuah aktivitas yang sangat penting untuk pertumbuhan dan perkembangan secara keseluruhan pada anak. Mengoptimalkan penguasaan keterampilan, sikap yang dapat menyebabkan perilaku hidup sehat, memfasilitasi perkembangan kognitif, dan sosial. Penelitian mengenai kejadian aktivitas fisik dikalangan anak-anak memperlihatkan asumsi bahwa sebagai anak-anak menciptakan gerak mereka sendiri. sedangkan orang tua dan pengasuh berasumsi bahwa aktivitas fisik disediakan melalui kegiatan bermain diberbagai tempat. Aktivitas tersebut mampu memberi stimulus terhadap perkembangan fisik dan motorik serta pertumbuhan besaran otot anak terhadap kesiapan akan usia remaja (Burhaein, 2017).

Upaya membimbing dan mendidik anak agar dapat mengembangkan potensi dirinya secara optimal maka guru, orang tua, dan yang berkepentingan dalam mendidik anak dianjurkan untuk memahami perkembangan anak. Pemahaman perkembangan itu penting sebab masa anak merupakan tahap perkembangan yang cepat dan memiliki perubahan dalam beragam aspek. Pengalaman masa kecil memiliki pengaruh yang sangat kuat dalam perkembangan selanjutnya, dan melalui pengetahuan kita dapat membantu mereka dalam mengembangkan diri dan memecahkan masalah, dapat mengantisipasi berbagai permasalahan dan kendala-kendala yang mampu mengontaminasi perkembangan anak, dan mampu memfasilitasi kebutuhan anak dalam perkembangannya (Syamsul, 2014).

Pengembangan potensi diri siswa selain dilakukan disekolah oleh guru harus dilakukan oleh orang tua juga yang menjadi peran utama dalam membimbing dan memperhatikan perkembangan anaknya. Tanpa adanya perhatian yang lebih besar dari orang tua perkembangan siswa kurang terarah dengan baik. Adanya perubahan-perubahan perkembangan anak yang masih labil dikarenakan masih dalam tahap perkembangan dasar. Salah satunya perkembangan yang harus diperhatikan adalah perkembangan fisikmotorik anak. Faktor yang mempengaruhi tumbuh kembang anak, yaitu:

a) Faktor lingkungan seperti: faktor fisik berupa keadaan cuaca, keadaan geografis suatu daerah, keadaan lingkungan masyarakat, keadaan rumah, dan radiasi).

b) Faktor psikososial: berupa motivasi belajar, simulasi, hukuman yang wajar, kelompok belajar, stres, kasih sayang, dan kualitas interaksi dengan teman sebaya, guru, orang tua serta orang dewasa. Sekolah Dasar merupakan lingkungan tempat belajar, sehingga setiap harinya siswa di sekolah pasti melakukan aktivitas gerak seperti bermain, belajar dan melakukan interaksi yang berpengaruh pada kemampuan motoriknya (Deliviana, 2017).

\section{Perkembangan Fisik Anak Usia Dasar.}

Perkembangan fisik merupakan suatu perkembangan yang menunjukan terjadiya perubahan bentuk tubuh anak, tinggi badan anak, berat badan anak, dan juga perkembangan otak anak. Pada Usia 6-12 tahun perkembangan fisik anak relatif lebih lambat dan konsisten. Perkembangan tersebut terjadi sampai perubahan besar pada awal masa pubertas (Tri, 2018). Perkembangan fisik anak dapat dilihat dari gambaran umumnya yang menyangkut pertambahan ukuran tinggi badan, berat badan, dan ciri fisik lainnya 
yang tampak. Anak usia dasar berada pada fase tenang, perkembangan fisik pada masanya terbilang lambat namun konsisten.

Ciri perkembangan fisik anak yang mendasar pada anak usia dasar 7 hingga usia 9 tahun, anak perempuan umumnya lebih pendek dan ringan dari pada anak laki-laki. Pada usia 9 sampai 10 tahun, anak perempuan lazimnya memiliki tinggi badan dan berat badan yang sama dengan anak laki-laki. Pada usia sekitar 11 tahun anak perempuan lebih tinggi dan berat dibandingkan anak laki-laki. Di usia ini, perkembangan anak lebih banyak kemampuan motorik dasarnya yang digunakan untuk menyeimbangkan badan, berlarilari, melompat, dan melempar (Trianingsih, 2016).

Akhir masa anak usia dasar berlangsung dari enam tahun sampai anak mencapai masa pubetas, yaitu: untuk anak perempuan sekitar sebelas tahun, dan untuk anak laki-laki sekitar dua belas tahun. Perkembangan fisik yang lambat dipengarui oleh imunisasi, asupan gizi, dan kesehatan. Keterampilan anak pada masa akhir dibagi kedalam 4 bagian, yaitu keterampilan menolong sosial, keterampilan sosial, keterampilan diri, dan keterampian bermain (Baharudin, 2016).

Perkembangan fisik anak usia dasar akan menentukan perilakunya sehari-hari secara langsung ataupun tidak langsung. Pertumbuhan fisik seorang anak akan menentukan terhadap keterampilan gerak anak. Secara tidak langsung perkembangan fungsi fisik akan mempengaruhi anak terhadap cara pandang kepada dirinya dan cara memandang orang lain. Pertumbuhan fisik anak dapat dikategorikan perkembangannya teratur, namun sering terjadi pula keanekaragaman perkembangan yang berbeda-beda disetiap waktunya. Ukuran bentuk tubuh yang diwariskan secara genetik dapat mempengaruhi lajunya perkembangan. Anak yang memiliki tubuh kekar dalam perkembangan fisik biasanya tumbuh secara cepat sedangkan dengan anak yang ukuran tubuhnya kecil atau sedang biasanya memiliki kelambatan dalam perkembangannya.

Karakteristik anak sekolah dasar yang berkaitan aktivitas fisik umumnya anak akan senang bermain, senang bergerak, senang bekerja dalam kelompok, dan senang praktik langsung (Alim, 2009). Berkaitan dengan konsep tersebut maka dapat dijabarkan:

Karakeristik pertama anak usia sekolah dasar senang Bermain. Seorang pendidik diharuskan paham dengan perkembangan anak, memberikan aktifitas fisik dengan model pembelajaran yang menyenangkan sehingga siswa mampu merasakan kesenangan seperti bermain ketika dalam kegiatan belajar. Materi pembelajaran dibuat dalam bentuk games, terutama pada siswa sekolah dasar kelas rendah (kelas 1,2, dan 3) yang masih cukup kental dengan zona bermain. Sehingga rancangan model ketka dalam proses pembelajaran berkonsep bermain yang menyenangkan, namun tetap memperhatikan ketercapaian materi ajar.

Karakeristik kedua anak usia sekolah dasar senang bergerak. Anak usia SD berbeda dengan orang dewasa yang telah mampu betah duduk berjam-jam, namun anak-anak tidak akan sama bahkan kemungkinan duduk tenang maksimal 30 menit dan itu semua hanya beberapa siswa saja. Sehingga peran pendidik harus mampu membuat pembelajaran yang senantiasa bergerak dinamis, permainan menarik yang memberi stimulus pada minat gerak anak.

Karakeristik ketiga anak usia sekolah dasar senang beraktifitas kelompok. Umumnya anak usia sekolah dasar senang mengelompok dirinya dengan teman se-usianya. Konsep pembelajaran dikelas dapat dibuat model tugas kelompok, dengan memberi materi melalui tugas sederhana untuk diselesaikan bersama. Tugas tersebut dalam bentuk gabungan dengan unsur psikomotor (aktifitas gerak) yang melibatkan unsur kognitif. Misal 
anak usia sekolah dasar diberi tugas materi gerak sederhana menjelaskan menembak bola (shooting), maka untuk dapat memperoleh jawaban mereka akan mempraktikkan dahulu kemudian baru memaparkannya sesuai dengan kemampuan masing-masing anak.

Karakeristik keempat anak usia sekolah dasar senang praktik langsung. Anak usia sekolah dasar senang melakukan kegiatan secara dipraktikan langsung, bukan teoritik. Berdasarkan ketiga konsep kesenangan sebelumnya yaitu: senang bermain, bergerak, berkelompok, tentu sangat lebih efektif dikombinasikan dengan praktik langsung. Pendidik memberikan pengalaman belajar anak secara langsung, sehingga pembelajaran lebih menyenangkan.

(Syamsul, 2014), Fisik atau tubuh manusia merupakan sistem organ yang kompleks dan sangat mengagumkan. Semua organnya terbentuk pada periode pranatal. Berkaitan dengan perkembangan fisik, kuhlen dan tomson mengemukakan bahwa perkembangan fisik individu meliputi empat aspek, yaitu:

a) Sistem syaraf yang sangat mempengaruhi perkembangan kecerdasan dan emosi.

b) Otot-otot yang mempengaruhi perkembangan kekuatan dan kemampuan motorik.

c) Kelenjar endokrin yang menyebabkan munculnya pola tingkah laku baru.

d) Struktur fisik/tubuh yang meliputi tinggi, berat, dan proporsi.

\section{Perkembangan Motorik Anak Usia Dasar.}

Perkembangan motorik merupakan proses perkembangan kemampuan gerak seseorang baik itu motorik kasar maupun motorik halus (Hidayati, 2010). Motorik kasar merupakan gerakan yang menggunakan hampir seluruh otot besar anggota tubuh. Sedangkan motorik halus merupakan gerakan yang menggunakan otot kecil dan koordinasi mata dengan tangan (Decaprio, 2013). Perkembangan motorik kasar maupun motorik halus pada anak-anak sangat dipengaruhi oleh perkembangan fisik. Kelengkapan dan kesehatan fisik anak merupakan salah satu yang memiliki pengaruh besar pada perkembangan motoriknya.

Keterampilan motorik berarti perkembangan keterampilan gerakan fisik melalui gerakan syaraf dan otot yang saling teratur. Kemampuan motorik dasar memiliki peran sebagai landasan terhadap keterampilan. Kemampuan motorik memiliki peranan penting dalam setiap kegiatan yang dilakukan (Wicaksono \& Nurhayati, 2013).

Masanya anak usia dasar yaitu senang bermain. Permainan menjadi wadah bagi anak untuk mengekspresikan semua potensi yang dimilikinya. Namun, sebuah kemajuan teknologi mampu memberikan dampak perubahan sikap anak yang dari banyak gerak kepada sikap diam atau sedikit gerak.

Hal ini mampu menyebabkanterjadinya gangguan proses metabolisme tubuh yang menjadikan terjadinya penurunan kesehatan, kesegaran jasmani, keterampilan, kreativitas, dan kecerdasan anak. Anak usia dasar merupakan bakal generasi penerus yang gilirannya tidak hanya ikut mewarnai jalannya pembangunan akan tetapi ikut menentukan kemajuan bangsa kearah yang lebih baik. Oleh karena itu anak usia dasar perlu dibina dan dikembangkan kemampuannya sehingga pada saatnya tidak hanya mampu menjadi sebagai pasilitator dan inovator, tetapi mampu berperan sebagai stabilisator dalam pembangunan kemajuan bangsa. Anak usia dasar merupakan individu yang selalu aktif melakukan kegiatan terhadap alam sekitar maupun terhadap diri sendiri. Anak usia dasar tidak hanya selalu ingin tahu tentang sesuatu, akan tetapi mereka selalu ingin mencoba dan mengalaminya sendiri. 
Perkembangan keterampilan motorik perupakan faktor yang sangat penting bagi perkembangan individu secara keseluruhan. Dengan adanya perkembangan motorik individu mampu menghibur diri dan memperoleh perasaan senang dari keterampilan motorik, memiliki keterampilan memainkan boneka, melempar, menangkap bola, memainkan alat-alat permainan, mampu menyesuaikan diri dengan lingkungan sekolah maupun masyarakat, dan mampu bergaul dengan teman sebaya (Syamsul, 2014).

Berdasarkan hasil wawancara dengan guru wali kelas 3 yaitu ibu Fifin. Bahwa dalam proses kegiatan belajar mengajar bu fifi setiap minggu mengganti tempat duduk siswasiswanya dengan catatan jika disetiap terhakhir kegiatan belajar siswa yang mampu menjawab pertanyaan guru boleh memilih teman sebangku, dan pengaturan tempat duduk yang mengatur hanya ibu fifin saja. Dengan begitu setiap siswa mampu merasakan tempat duduk disetiap sudut kelas. Agar kegiatan belajar disekolah tidak membosankan bu fifi memberikan refleksi ditengah kegiatan belajarnya dengan sebuh games edukasi yang mampu mengembalikan gairah siswanya dalam belajar. Selain itu adanya kegiatan senam dalam seminggu sekali untuk seluruh siswa di sekolah dasar negeri tajem.

Dilihat dari aspek perkembangan fisik tersebut telah memberikan sedikit kejelasan bahwa perkembangan fisik siswa yang telah diamati pada sekolah dasar negeri tajem kelas 3 dari segi kecerdasan seluruh siswa memiliki kecerdasan berbeda. Perbedaan itu dapat dilihat dari ketepatan dan kecepatan dalam menjawab soal atau mengerjakan tugas, serta pemahaman terhadap materi yang disampaikan guru. Selanjutnya dalam segi emosi siswa kelas tiga telah mampu menurunkan sedikit emosinya meski terkadang pada emosi dari masing-masing siswa ada yang sesekali memuncak akan tetapi siswa tersebut akan menyadari sendiri kesalahannya dan akan berdamai dengan temannya yang lain atas perlakuan emosi yang telah diperbuatnya. Kemandirian dalam masing-masing siswa telah terlihat dari bagaimana cara mereka menyikapi permasalahan-permasalahan yang terjadi didalam kelas.

Survey kemampuan motoriknya seluruh siswa kelas 3 bagus, sehingga tidak ada siswa yang memiliki gangguan. Seluruh siswa kemampuan dalam bersosialisasi dan dalam melakukan kegiatan sehari-hari baik juga yang menjadikan seluruh siswa mampu melakukan serangkaian kegiatan di sekolah dan di rumah. Seluruh siswa aktif dalam mengikuti kegiatan belajar. Ketika memiliki tugas menulis dari bu fifin, seluruh siswa mampu menyelesaikannya dengan kategori waktu yang berbeda dan tulisan tangannyapun berbeda. Ketika dalam tugas kegiatan prakarya seluruh siswa mampu menggunting gambar sesuai pola, membentuk garis (panjang, bundar, melengkung, dan bentuk lainnya) telah rapih dan sesuai gambar yang diinginkan.

Ketika proses pembelajaran bu fifin selesai menjelaskan materi, beberapa siswa menanyakan kembali materi yang tidak dimengertinnya. Sebagain siswa ada yang mengikuti kegiatan les dan ada juga yang melakukan kegiatan belajar bersama orang tuanya dirumah dan ada juga yang malah bermain dengan teman sebaya tapi pada waktu tertentu yang telah disepakati dengan orang tuanya dirumag. Sehingga seluruh siswa kurang lebih mampu memahami materi dengan baik dan ketika ada kesulitan dalam memahami materi siswa akan menanyakan ulang apa yang tidak mereka mengerti.

Terkait karakteristik siswa pada aktivitas fisiknya yang senang bermain, bergerak, berkelompok, tentu sangat lebih efektif dikombinasikan dengan praktik langsung yang kemudian terealisasikan dalam kegiatan olahraga. Kegiatan olahraga juga merupakan salah satu kegiatan dalam mengasah dan menguatkan terhadap perkembangan fisik dan 
motoriknya. Siswa dilatih gerakan kakinya berupa bagaimana cara berlari cepat, melompat untuk mengasah kekuatan kaki dalam menopang, dan berjalan maju dan berjalan mundur dalam menyeimbangkan badannya. Dakam kegiatan bermain kelompok berupa kegiatan olahraga volly ball dan sepak bola ataupun futsal. Pada kegiatan ini siswa diajarkan kekompakan dan dilatih kekuatan tangan dalam menerima bola dan melemparnya lagi, dilatih kekuatan kaki dalam menendang bola untuk bisa masuk pada gawang lawan dan bagaimana cara mengoper bola pada teman satu tim, serta masih banyak kegiatan olahraga lainnya yang bisa membuat perkembangan fisik dan motoriknya berkembang dengan baik.

\section{Kesimpulan}

Perkembangan fisik-motorik merupakan satu kesatuan yang tidak dapat dipisahkan karena keduanya saling berkaitan. Perkembangan motorik merupakan peran utama dalam tercapainya perkembangan fisik yang baik. Dengan berbagai macam kegiatan yang guru lakukan disekolah dalam mengembangkan perkembangan fisik-motorik anak kearah yang lebih baik lagi dalam prosesnya telah memperlihatkan bahwa seluruh siswa kelas 3 dalam perkembangan fisik-motorik telah bagus, mereka mampu mengikuti semua arahan yang disampaikan oleh gurunya yang kemudian perkembangan fisik-motorik anak tercapai dengan baik dan sempurna.

\section{Daftar Pustaka}

Alim, A. (2009). Permainan Mini Tenis Untuk Pembelajaran Di Siswa Sekolah Dasar, Jurnal Pendidikan Jasmani Indonesia, 6(2), pp. 61-63. Available at: https://journal.uny.ac.id/index.php/jpji/article/view/434.

Baharudin. (2016). Pendidikan dan Psikologi Perkembangan. Yogyakarta: Ar-Ruzz Media.

Burhaein, E. (2017). Aktivitas Fisik Olahraga untuk Pertumbuhan dan Perkembangan Siswa SD, Indonesian Journal of Primary Education, 1(1), p. 51. doi: 10.17509/ijpe.v1i1.7497.

Wicaksono, C., \& Nurhayati, D.F. (2013). Survey Kemampuan Motorik Siswa Sekolah Dasar Muhammadiyah Kelas IV Se-Kecamatan Taman Sidoarjo Tahun Ajaran 2012-2013. Jurnal Pendidikan Olahraga dan Kesehatan, 1(1), pp. 98-103. Available at: https://jurnalmahasiswa.unesa.ac.id/index.php/jurnal-pendidikanjasmani/article/view/2808.

Decaprio, R. (2013). Aplikasi Teori Pembelajaran Motorik di Sekolah. Yogyakarta: Diva Press.

Deliviana, E. (2017). Mempersiapkan Anak Masuk Sekolah Dasar, Jurnal Dinamika Pendidikan, 10(2), pp. 119-133. Available at: http://ejournal.uki.ac.id/index.php/jdp/article/view/611.

Emzir. (2012). Metodologi Penelitian Kualitatif Analisis Data. Jakarta: PT. RajaGrafindo Persada. 
Hidayati. (2010). Anak Saya Tidak Nakal Kok. Yogyakarta: B First.

Munirotul, H. (2013) Implementasi Kebijakan Program Gerakan Literasi Sekolah (GLS) Di Sd Muhammadiyah Bantul Kota, Journal of Chemical Information and Modeling. UIN Sunan Kalijaga Yogyakarta. doi: 10.1017/CBO9781107415324.004.

Puspita, D., Calista, W., \& Suyadi, S. (2018). Perkembangan Fisik-Motorik Siswa Usia Dasar: Masalah Dan Perkembangannya. JIP (Jurnal Ilmiah PGMI), 4(2), 170-182.

Rinaldi, M.S. (2019). Tingkat Kemampuan Motorik Siswa Kelas Atas Di Sekolah Dasar Negeri Gadingan Wates Tahun 2018/2019. Jurnal Pendidikan Jasmani Kesehatan dan Olahraga, (2), pp. 2-5.

Suharsimi, A. (2010) Manajemen Penelitian. Jakarta: PT.Rineka Cipta.

Syamsul, Y. (2014). Psikologi Perkembangan Anak dan Remaja. Bandung: PT.Remaja Rosdakarya.

Tri, M. (2018). Perkembangan Fisik Motorik Dan Perseptual Serta Implikasinya Pada Pembelajaran Di Sekolah Dasar. Wahana Sekolah Dasar, (1), pp. 21-28. Available at: http://journal2.um.ac.id/index.php/wsd/article/view/2871/1730.

Trianingsih, R. (2016). Pengantar Praktik Mendidik Anak Usia Sekolah Dasar, Jurnal Al Ibtida, 3(2), pp. 197-211. Available at:

http://www.syekhnurjati.ac.id/jurnal/index.php/ibtida/article/view/880. 